\title{
AN EASY SALE
}

\author{
Time for an upgrade.
}

\section{BY BIREN SHAH}

$\mathrm{W}$ hen the perky birthsuiter girl came to greet him, Allen's EPU - emotion processing chip interrupted normal conscious processing and adjusted internal state variables to disappointment.

"Hi, I'm Jeannette," the girl said with a big smile.

"Are you sure we can't do this over the net?” Allen asked.

"Don't be silly. You're already here." She turned on one high heel.

Allen centred his visual focus below the edge of her black pinstriped skirt-suit, watching the smooth skin of her calves ripple as she walked into the conference room. He instructed follow, and a subroutine activated his leg actuators. After a few nanoseconds, his positional readings began to change. His visual cortex reallocated resources to handle the optic flow, shrinking the area he could see in focus. It's just like them, he thought. They don't know a damned thing about their customers.

When he finally made it into the chair across from her, she said: "You've been a vocal critic of most of our releases since the 116 series you're wearing now -"

He began queuing up his response. "You keep introducing upgrades for huge profits and keep gouging your customers ..."

As his voice modulator processed and spoke his words, Jeannette flipped her lush black hair and rubbed the brown skin of her neck with the back of her hand. Her tendons pulled tight, framing the hollow of her neck in a little v.

If they were jacked in, he'd be the one waiting on her. And there certainly wouldn't be any distractions like this.

His EPU launched the memory of his last touch. He and his wife had been outside, sitting on a lawn. The sun warmed his shrivelled flesh. A weak breeze cooled his left arm from behind. She sat between his legs, leaning against him as his atrophied muscles strained to hold their weight. He'd insisted he get to be the one to hold her despite her protests that he was too weak from the chemo. It had been his last chance to feel like a true man. He leaned closer, just by having the desire, and her blond hair tickled his ear as it fluttered against him. He took a deep breath to commit the smell of her - vanilla and jasmine and a touch of sweat - to memory. His fingers stuck to her glistening pale skin as he caressed her arm, then slipped only to catch again. Goosebumps rose where he had touched.

It was one of his last birthsuit memories, stored perfectly in the artificial brain housing his mind. He could go back to that moment and re-experience every sensation.

He never did.

"I'm familiar with your objections," Jeannette said.

Allen realized he'd just trailed off. This beautiful girl had him swimming in those terrible currents of sensation again. $\mathrm{He}$ shut down the memory-playing process - but he had to wait for his emotion chip to flush his state buffer of the downward accelerometer reading meant to simulate a sinking feeling of loss. “Then you know I've added every feature you released since the 116 s aftermarket for a tenth of the cost of an upgrade."

"I'm not here to argue that with you." She leaned forward and Allen couldn't pull his visual focus from a flash of cobalt blue satin where her jacket parted.

"Enjoying the view?" she asked. The salmon-coloured chromoplasts in Allen's cheeks flared. His central clock rate accelerated.

"Don't worry - it's kind of why we're here." Jeannette stood up and removed her jacket. "Although you're right that most customers got only aesthetic value out of the 200s, 300 s and 400 s, those models laid the groundwork for a huge leap forward in our $\rightarrow$ NATURE.COM Follow Futures on Facebook at: go.nature.com/mtoodm product map." She turned around. The blue blouse cut down to her waist, exposing the unblemished skin of her back. She pressed against her neck and a small flap appeared. She pulled on it gently, peeling the skin away to reveal a titanium alloy spine.

"That's not a birthsuit." Allen struggled to get the words queued up between his EPU's rapid-fire interrupts.

"No, you're getting an advanced look at the 500 - all the technologies we've been developing for the past 150 years wrapped in a biological prosthetic." She pushed her skin back in place and sat down.

Allen focused on her forearm and instructed index-finger forward-back, forward-back. His finger reached out and poked her twice. "Does this feel ... right?"

"The 500 is virtually indistinguishable from a birthsuit, from inside and out."

Allen focused on her hand and instructed palm surface dock (tolerance: $30 \mathrm{~cm}$ of current position) followed by $5 \mathrm{~cm}$ forward-back, 15 seconds. His hand rubbed the back of her hand. The sensory feedback came back like he was rubbing a pan with a spatula.

"We want to offer you an upgrade, free of charge."

Manipulation-warning subroutines fired, but Allen dismissed them and shut down the monitoring process. What did she feel like? Smell like?

"Your blog reaches nearly 10 million of our most savvy customers. As great as the 500s are, after an initial exploring phase, our beta testers regularly end up weighing over 300 pounds. Obviously, this causes some dissatisfaction."

Allen zoomed his visual field in on the shape-shifting of her mouth as she talked. He tried to remember what it was to have such a mouth - supple, responsive ...

"We want you in our PR department, educating our customers on the maintenance requirements of a biological prosthesis. We're thinking for say a period of 50 years?"

A contract appeared in Allen's inbox. With a single thought, he signed the document with his public key and sent it back. "What was that about dissatisfaction?"

"Never mind," she answered after a screen in the table flashed a message. "You won't have the same problems. I can tell."

Biren Shah has recently moved to New York City, changed careers, and started writing again. He's exploring as fast as he can. You can watch at www.birenshah.com. 